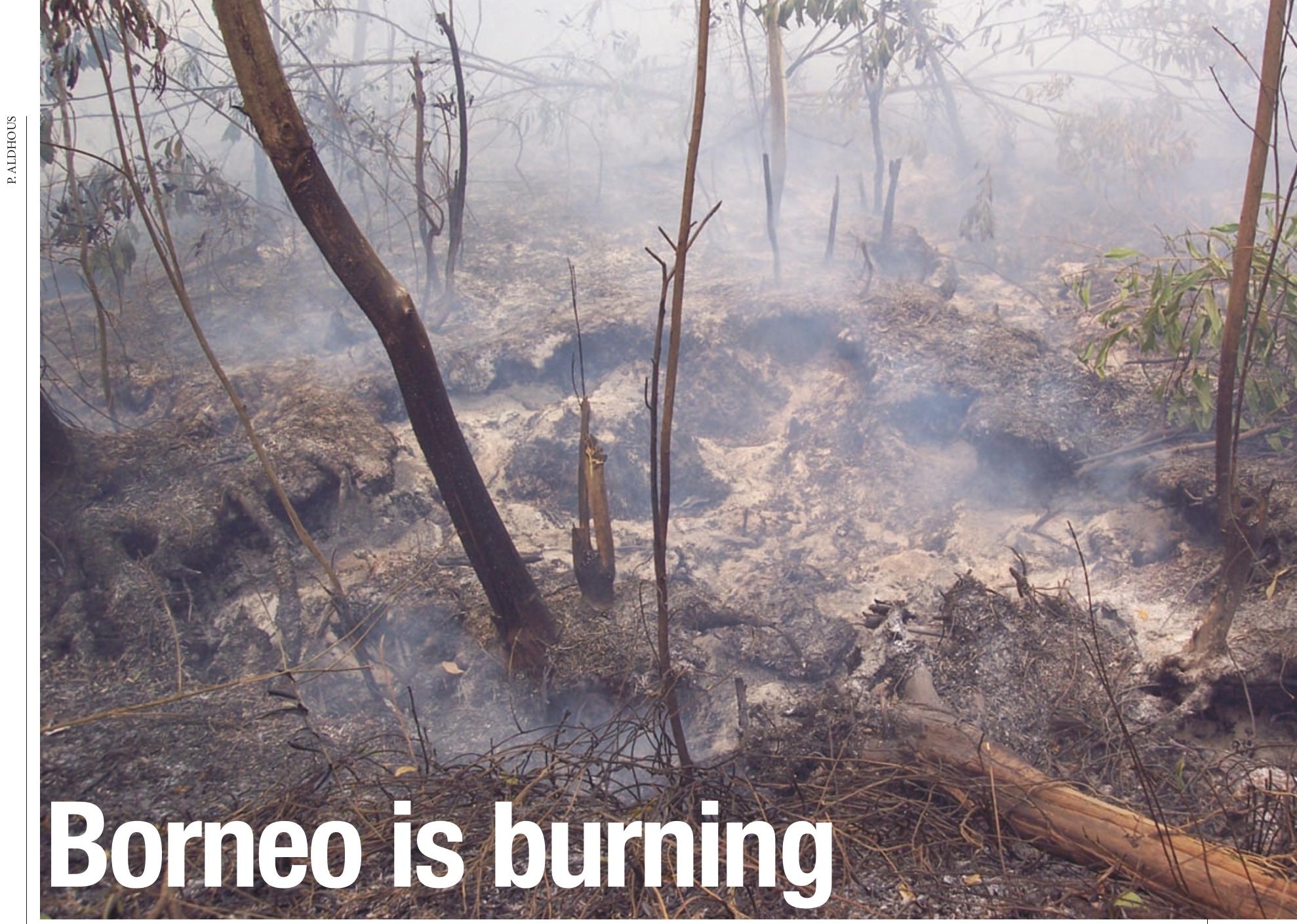

Vast tracts of Indonesia's peat swamps have been drained in a misguided attempt to turn them into rice plantations. Now the landscape burns every year, belching smoke and hastening global warming. Peter Aldhous investigates.

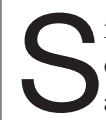

itting in a small boat at the junction of two drainage canals, all I can see are walls of crumbling peat piled up to four metres high. On these parched banks, nothing grows. In some spots, smoke rises from the debris, while elsewhere patches of yellow, acidic sediments taint the peat. Overhead the Sun hangs orange-red, peering bleakly through a smoky shroud.

It's like a post-apocalyptic wasteland. Certainly 'apocalypse' is an apt description for what happened here in the Indonesian province of Central Kalimantan, in the south of the island of Borneo. This area was, until recently, a lush swamp forest that had lain undisturbed for thousands of years. But a single, wantonly inept decision by Indonesia's former dictator, Suharto, changed all that. Suharto wanted to turn Borneo into the rice bowl of Indonesia. But he succeeded only in creating a smouldering heap of ash that blights the lives of local people — and threatens to destabilize the global climate by belching vast quantities of carbon dioxide into the atmosphere.

I'm here to meet the scientists and environmentalists who are assessing the damage, and are taking the first tentative steps towards a solution by blocking some of the drainage canals using hand-built dams. It will be an uphill struggle, but they hope to show that it is possible to stop the annual fires that choke and char this landscape, and to return the devastated swamps to life.

Much of the Indonesian archipelago is blanketed in a layer of peat - forest litter too wet to rot that has accumulated over thousands of years. Over decades, these forests have been slowly cleared and drained. But matters took a sharp turn for the worse in 1995. Fertile land on the overpopulated island of Java was needed for housing and industry, so Suharto announced that more than one million hectares in Central Kalimantan — an area about a third the size of Belgium would be switched to rice production.

Over the next two years, loggers felled the forests, while contractors dug some 4,600 kilometres of drainage canals, the largest of them 30 metres wide (see Map, opposite). Tens of thousands of landless Javanese were brought in to tend the Mega Rice Project, as the plan was known.

Borneo's native Dayak people could only watch as their forests and the traditional livelihoods they had supported were destroyed. "First we were colonized by the Dutch, now we are colonized by Java," says Suwido Limin, whose team at the University of Palangkaraya, in the heart of the devastated area, studies the swamps. A fiercely proud Dayak, Limin was a vocal opponent of the plan from the start.

\section{Sucked dry}

The canals were laid down in a pattern that, in Java, keeps the soil well drained and irrigates crops with river water. But here in Borneo, the peatland topography rendered it useless. The peat is piled up into domed structures that rise to several metres above river level. Even a dictator's decree can't make water run uphill, so the canals simply sucked the peat dry. At the same time, the peat also proved too acidic to grow rice. Suharto had been told as much by the few local experts who were prepared to speak out. But the plan 


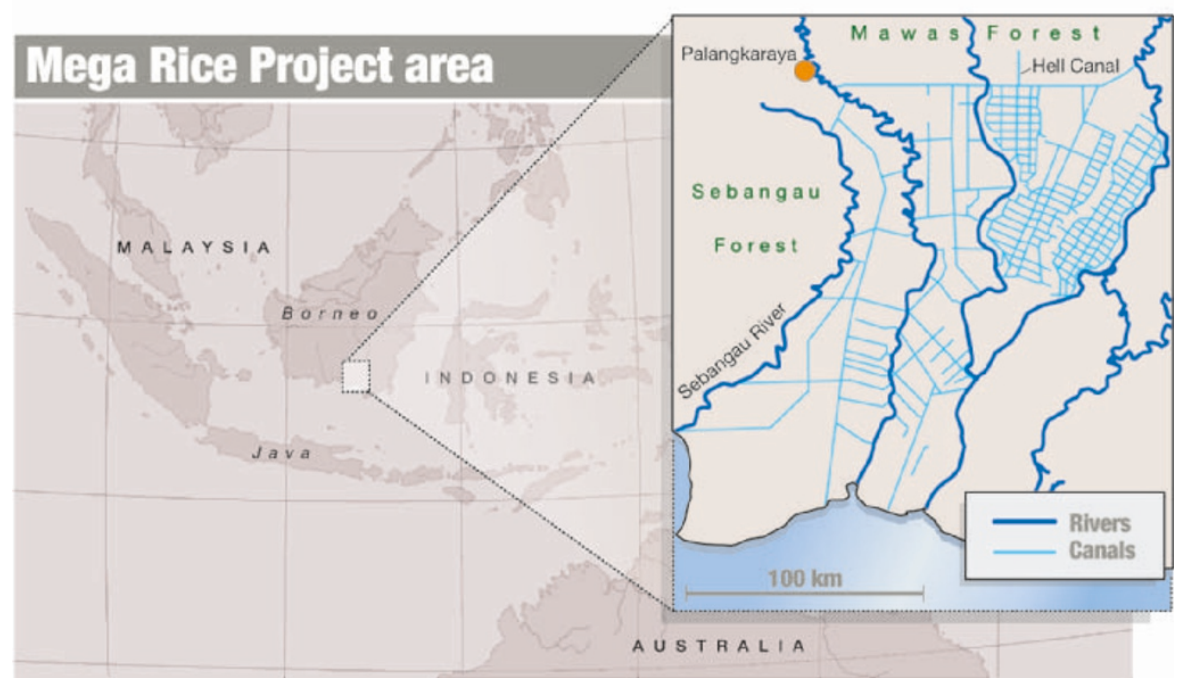

Canals carved through Kalimantan (above) have wrecked its peat swamps. Now locals are trying to dam the waterways and restore the area (below).

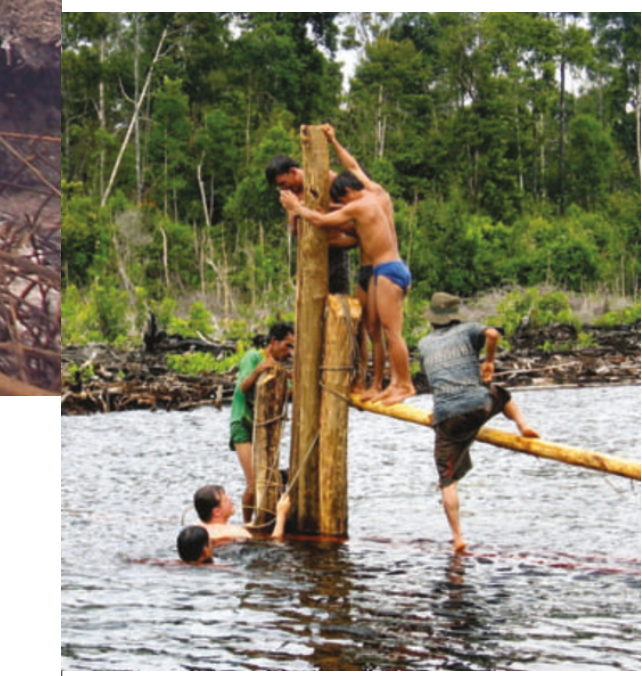

went ahead anyway - buoyed by the lure of lucrative construction contracts doled out to associates of his regime.

In the end, the Mega Rice Project yielded barely a grain. Its failure occurred against a background of economic meltdown and rioting across much of Indonesia. In Kalimantan, there was an orgy of bloodletting as the downtrodden Dayaks turned on Muslim settlers. Some returned to the gruesome headhunting practices of earlier generations, invoking the spirits of their ancestors in pre-battle rituals. The newer migrants brought in for the Mega Rice Project mostly avoided the violence. But with no economic incentive to stay, many fled Borneo.

Today, Kalimantan's tensions have subsided. Suharto was forced to step down in 1998, and the Mega Rice Project was abandoned shortly afterwards. But the drainage of the swamps has left a legacy of fire that returns each year during the dry season, from July to late October. Some fires are started deliberately to clear land for cultivation; others result from carelessly tossed cigarettes.
This October, street life in Palangkaraya, the capital of Central Kalimantan, is accompanied by the constant whiff of smoke. Drive outside the city's limits, and you are soon in a smoggy haze. There are few flames, but the peat can smoulder for days. At one point, a fallen treeblocks the road - the peat in which it grew has literally burned away. Standing by the roadside, my eyes are streaming.

\section{Burnt out}

But this isn't a particularly bad year. Things really go to hell during the reversal of Pacific currents known as El Niño, which brings drought to the region. In 1997, the strongest El Niño on record encouraged fires that cut visibility in Palangkaraya to less than ten metres for almost three months. "Many people went to hospital with lung problems," recalls Alue Dohong, a local environmentalist. The city's airport was closed, and traffic on Kalimantan's rivers - the lifeblood of the area's struggling economy — was disrupted as boats collided in the smog.

Fires burned out of control across Indonesia for months. The haze extended across southeast Asia, and cost more than US $\$ 4.5$ billion in lost tourism and business ${ }^{1}$. The burning peat resulted in the largest annual increase in levels of carbon dioxide in the atmosphere since records began in the 1950s (ref. 2). analysed by Annette Bechteler, a student at the University of Munich in Germany, the 1997 disaster torched more than 2.7 million hectares in Central Kalimantan. And we can expect more of the same. In 2002, a weak El Niño saw the fires return. Given that the peat is more than 12 metres deep in places, it will burn again and again, each time drought returns.

Even what's left of the swamp forest isn't safe. The Mega Rice Project has lowered the water table in neighbouring areas, and some of the remaining migrants it attracted have now taken to illegal logging. This makes the
According to satellite data forest vulnerable to fire, and threatens the survival of Borneo's last orangutans (see 'The orang's last stand', overleaf).

Most of what we know about Kalimantan's peat swamp forest, and the consequences of its destruction, comes from projects based at Limin's Centre for International Co-operation in Management of Tropical Peatland, or CIMTROP. In 1993, Limin and Jack Rieley, a peatland ecologist at the University of Nottingham, UK, began surveying an area of peat swamp in the Sebangau river basin, south of Palangkaraya. Today, their field site forms part of a 50,000hectare 'natural laboratory'. You reach it by riding in a motorized cart on a rickety railway laid on stilts rising from the peat.

\section{Up in smoke}

Rieley and his colleagues - including his wife Sue Page, an ecologist at the University of Leicester, and Florian Siegert, a remotesensing expert at the University of Munich - revealed the huge impact of Indonesia's fires on global climate. By combining satellite data and field observations, they estimated that the 1997 fires released 13-40\% as much $\mathrm{CO}_{2}$ as a typical year's global emissions from burning fossil fuels ${ }^{2}$.

The Sebangau swamp has been absorbing $\mathrm{CO}_{2}$ and storing it in peat for the past 26,000 years ${ }^{3}$. Now, one of the planet's most important carbon sinks is poised to become a major source of the gas. Even without burning, the prospects aren't good. As soon as a swamp is drained, bacteria begin oxidizing the dried peat, releasing its stored carbon. "Fire hastens a process that is going on anyway," says Page.

The key to reversing the damage is to raise the water table, and to plant saplings in the remoistened peat. My boat trip was with a team monitoring an initial attempt to do just this. The Climate Change, Forests and Peatlands in Indonesia (CCFPI) project involves the environmental groups Wetlands International and Wildlife Habitat Canada. Given US\$3.2 million over five years by the Canadian government, CCFPI is
"The 1997 fires released up to $40 \%$ as much $\mathrm{CO}_{2}$ as a typical year's global emissions from burning fossil fuels." working with local people and officials to prevent fires in both Borneo and Sumatra - where large areas of peat swamp have similarly been drained.

In the northernmost of the Mega Rice Project's canals, CCFPI is building dams to try to keep the peat saturated. It's a tall order, given that the dams must be constructed by hand, using local materials plus supplies brought in by boat. And at best, CCFPI's efforts can only demonstrate what needs to be done on a vast scale. "If this model works, we can get more funds from other sources," suggests Faizal Parish, who heads the Global Environmental Centre, based just outside Kuala Lumpur in Malaysia, which has orchestrated support for CCFPI.

Each dam's frame comprises two walls of 
logs driven vertically into the sediment and bolted together. Logs are lowered into position by a pulley system, and then pile-driven by people jumping up and down on a crossbeam. The dam is then lined with impervious textile, before being packed with sandbags filled with clay.

CCFPI has so far built seven dams, with mixed success. At our base camp, the dam across the main canal draining from west to east is holding up well, maintaining a head of water more than a metre high. Several kilometres to the west, on the 'Hell Canal' cut northwards into the relatively pristine Mawas Forest, the upper of two dams is doing even better: the water level upstream is about two metres higher than below.

But the lower of the two Hell Canal blocks is doing little to impede the remaining flow. Its builders apparently failed to clear its base of tree stumps and loose debris before piling in the sandbags. Another dam on the main canal has been breached, bowed by the weight of water bearing down on it. Local people have also removed sandbags to create a slipway for their boats. "Perhaps we need better construction guidelines and supervision," says Parish.

Limin, Rieley and their CIMTROP collaborators also plan to block some of the Mega Rice Project's drainage canals using similar

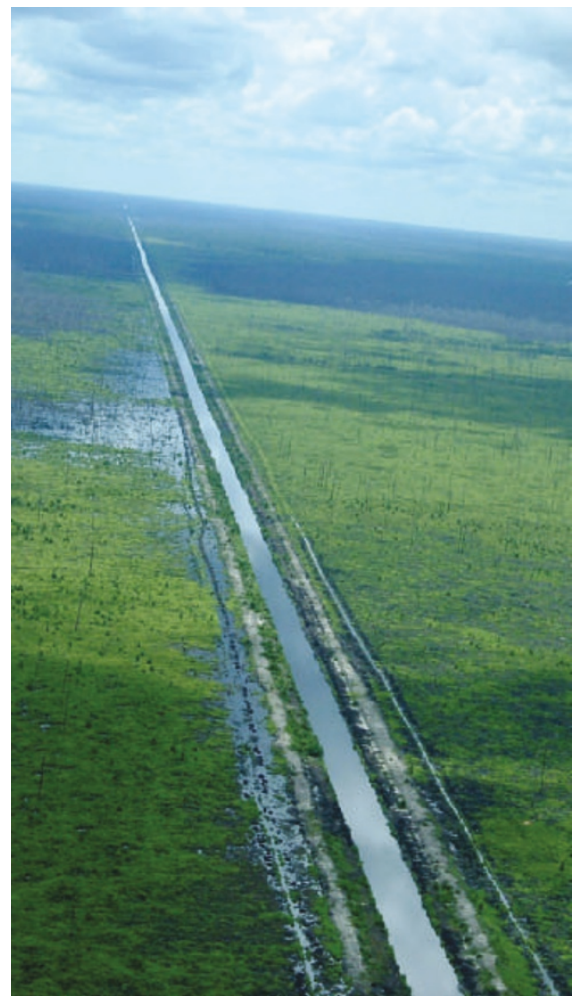

Drained: the canals cut through southern Borneo have sapped the peat swamps of life.

\section{The orang's last stand}

Central Kalimantan still has large expanses of peat swamp forest that haven't been drained and cleared for agriculture. But even here negative effects of the Mega Rice Project are being felt. Out-of-work migrants have raided these forests for wood, digging ditches to float away the most valuable trees. This could spell disaster for the endangered orangutan, for whom these forests are the most important remaining habitat.

Orangutans (pictured) used to range freely all over Borneo and Sumatra. But as the most accessible forests have been felled, populations have become concentrated in the swamps. Today, there are thought to be about 57,000 orangutans left in the wild ${ }^{4}-$ with the largest single population, of 6,900 individuals, in the Sebangau peat swamp forest south of Palangkaraya.

Simon Husson and Helen Morrogh-Bernard - both graduate students at the University of Cambridge, UK - say that there were as many as 13,000 orangutans in Sebangau in the late 1990s. But the population crashed in 2000-01, mostly thanks to illegal logging. Orangutans spend much of their lives up in the trees, and are highly sensitive to disturbance. "They don't like being in an area in which the trees are falling down," says Husson. His and MorroghBernard's unpublished work suggests that the animals were forced into smaller areas of pristine forest, where food shortages caused many to starve.

Loggers in Sebangau are currently being dissuaded by a patrol team operating from the University of Palangkaraya. But the orangutan population won't bounce back any time soon - an adult female typically has only one baby every seven years. And, ominously, loggers are still operating in the Mawas Forest to the northeast, in which the Borneo Orangutan Survival Foundation is trying to establish a reserve.

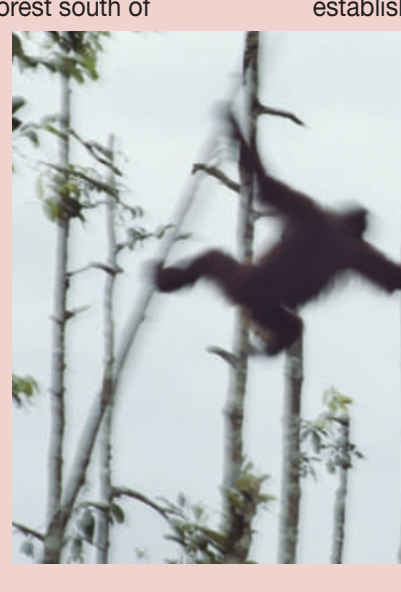

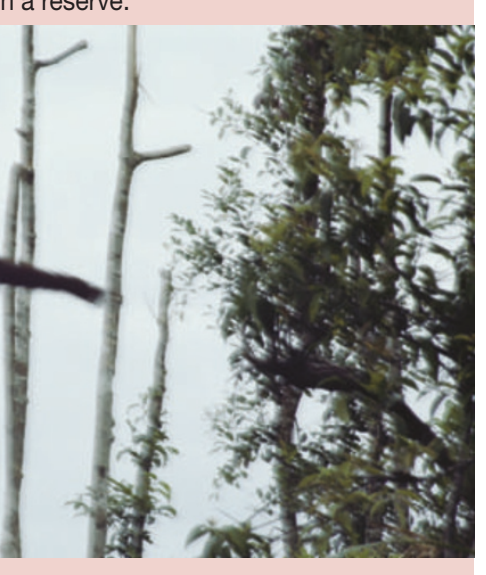

techniques. Construction of their first two dams will start in the coming weeks, using Finnish funding brought in by Jyrki Jauhiainen, an ecologist at the University of Helsinki. Further dams will be built as part of a European Union project on restoring tropical peatlands, which has just won a grant of $€ 1.5$ million (US\$1.9 million) over three years.

\section{Gas check}

The CIMTROP projects will not only monitor rising water levels, but will also track the effect this has on $\mathrm{CO}_{2}$ emissions from the peat. A Japanese team from Hokkaido University already has a mass of data from automated $\mathrm{CO}_{2}$ sensors. Jauhiainen will take similar measurements before and after his dams are built, to see if emissions are, as predicted, reduced by the retention of water.

If any of these efforts are to work, the people of Central Kalimantan must be brought on board. "It's very important to have a local community involvement," says Dohong, who is CCFPI's Kalimantan coordinator. CCFPI is providing loans to impoverished peatland villagers to buy livestock; if they plant tree seedlings, and protect them from fire, the loan won't have to be repaid. And because the trees include species that can be tapped for gum, they will provide another source of income once they mature.

Political commitment will be crucial, too. Samsi Kulu, head of the planning department for the district covering CCFPI's dams, is convinced of the need to block more canals. But he is frustrated by contrary policies enacted by the central government. Even today, its contractors are dredging some of the Mega Rice Project canals in a misguided attempt to 'rehabilitate' the area using methods suitable only for other landscapes. "It's just making the situation worse,"laments Kulu.

One the biggest fears of those trying to restore the damaged peat swamps is that their efforts could sink in the mire of Indonesian politics - now facing a shake-up with the inauguration of the country's first directly elected president, Susilo Bambang Yudhoyono, on 20 October. He will soon be presented with a plan recommending that some parts of the Mega Rice Project area continue to be farmed - perhaps for oil palms - whereas others are earmaked for conservation. But the details remain unclear.

In the meantime, the pilot efforts of CCFPI and the CIMTROP researchers can do little to prevent hundreds of thousands of hectares going up in smoke the next time El Niño returns. "It will take 20 years to fix this problem," says Parish.

Peter Aldhous is Nature's chief news \& features editor.

1. Glover, D. \& Jessup, T. (eds) Indonesia's Fires \& Haze: The Cost of Catastrophe (International Development Research Centre/Institute of Southeast Asian Studies, Singapore, 1999). 2. Page, S. E. et al. Nature 420, 61-65 (2002).

3. Page, S. E. et al. J. Quaternary Sci. 19, 625-635 (2004).

4. Singleton, I. et al. (eds) Orangutan Population \& Habitat Viability Assessment: Final Report (IUCN/SSC Conservation Breeding Specialist Group, Apple Valley, Minnesota, 2004.) 